\title{
Re-emergence of Chorioptes bovis (Acari: Psoroptidae) in cattle in the state of Rio Grande do Sul, Brazil
}

\author{
Reemergência de Chorioptes bovis (Acari: Psoroptidae) em bovinos no Estado do Rio Grande do Sul, Brasil \\ Maria Isabel Botelho Vieira ${ }^{1 *}$; Tiago Bordin²; Bruno Dall’ Agnol'3 Fabiane Zanchin ${ }^{4}$; \\ Adriana Costa Da Motta'; Mirela Noro
}

\author{
${ }^{1}$ Veterinary Parasitology Laboratory, School of Agronomy and Veterinary Medicine - FAMV, University of Passo Fundo - UPF, Passo \\ Fundo, RS, Brazil \\ ${ }^{2}$ Veterinary Endocrinology, Integrated School - AVM, Rio de Janeiro, RJ, Brazil \\ ${ }^{3}$ Molecular and Cell Biology, Pontifical Catholic University of Rio Grande do Sul - PUCRS, Porto Alegre, RS, Brazil \\ ${ }^{4}$ Veterinary Sciences, Federal University of Rio Grande do Sul - UFRGS, Porto Alegre, RS, Brazil \\ ${ }^{5}$ Animal Pathology Laboratory, School of Agronomy and Veterinary Medicine - FAMV, University of Passo Fundo - UPF, Passo \\ Fundo, RS, Brazil \\ ${ }^{6}$ Federal University of the Pampa - UNIPAMPA, Uruguaiana, RS, Brazil
}

Received April 19, 2014

Accepted September 3, 2014

\begin{abstract}
Here we describe an outbreak of chorioptic mange in cattle, 56 years after its first identification in Brazil. Between the months of June and July 2011, dermatitis characterized by alopecia and crusted and thickened skin at the insertion of the tail and in the ischiorectal fossa was recognized in $40(35.7 \%)$ out of 112 Holstein cows on a farm in the northeastern mesoregion of the state of Rio Grande do Sul, Brazil. After diagnosing mange caused by Chorioptes bovis, the cows were weighed and treated with $0.5 \%$ ivermectin, as a pour-on single dose, and were separated into two groups: cows in early lactation and those in late lactation. The survival rate of $C$. bovis and the healing rate in the two groups of infested cows were monitored every seven days through skin scrapings. After 28 days of evaluation, the cure rate through treatment was greater among cows in early lactation $(p<0.0001)$. The survival rate of $C$. bovis was higher in cows in late lactation.
\end{abstract}

Keywords: Chemical control, ivermectin, mange, dairy cows.

\section{Resumo}

O objetivo deste estudo foi descrever um surto de sarna corióptica em bovinos, 56 anos após a sua primeira identificação no Brasil. Entre os meses de junho a julho de 2011, a dermatite caracterizada por alopecia, com crosta e espessamento da pele na inserção da cauda e na fossa isquiorretal, foi observada em $40(35,7 \%)$ de 112 vacas holandesas de uma propriedade rural pertencente à Mesorregiáo do Nordeste do Estado do Rio Grande do Sul, Brasil. Após o diagnóstico da sarna causada por Chorioptes bovis, as vacas foram pesadas, tratadas com $0,5 \%$ de ivermectina pour on em dose única e separadas em dois grupos: vacas no início da lactação e no final da lactação. A taxa de sobrevivência de C. bovis e a taxa de cura dos dois grupos de vacas infestadas foram monitoradas a cada sete dias por meio de raspas de pele. Após 28 dias do estudo, a taxa de cura com o tratamento foi maior em vacas no início da lactação $(p<0,0001)$. A taxa de sobrevivência de C. bovis foi maior em vacas no final da lactaçáo.

Palavras-chave: Controle químico, ivermectina, sarna, vacas leiteiras.

\footnotetext{
*Corresponding author: Maria Isabel Botelho Vieira, Laboratório de Parasitologia Veterinária - LPV, Faculdade de Agronomia e Medicina Veterinária - FAMV, Universidade de Passo Fundo - UPF, Campus I, BR 285, Km 171, Bairro São José, CEP 99001-970, Passo Fundo, RS, Brasil, e-mail: marisabel@upf.br
} 


\section{Introduction}

Mange is a widespread disease affecting various animal species, and it is transmitted by both direct and indirect contact (JONES et al., 2008). Chorioptic mange is considered to be the most common form of scabies in the northern hemisphere and is caused by Chorioptes bovis (C. bovis) (HERING, 1845) and Chorioptes texanus (HIRST, 1924) (REHBEIN et al., 2005). Both species have been recorded in cattle in Brazil (FACCINI \& MASSARD, 1976; FACCINI \& LEITE, 1996). Records of the disease were made by Oba et al. (1977) in female Holstein cattle in São Carlos, state of Sáo Paulo, and Fernandes et al. (1972) in the state of Paraná.

Chorioptic mange is observed in adult cattle, especially in dairy cows, and is observed in well-managed herds. Parasitosis occurs during the winter period, when cattle are stabled, and results in clinical signs (lesions and itching) that usually disappear when the animals return to pasture in the spring. However, among animals that remain confined throughout the year, the lesions tend to persist to varying degrees. These lesions begin at the root of the tail (REHBEIN et al., 2005). The diagnosis of scabies is based on the history of the disease, clinical signs and laboratory confirmation through identification of the mites in skin scrapings (YERUHAM et al., 1999).

Here, we report on an outbreak of chorioptic mange in Holstein cows, highlighting its clinical aspects, diagnosis and cure rate and the survival of mites after treatment with $0.5 \%$ ivermectin in pour-on form, among cows in early lactation and late lactation.

\section{Materials and Methods}

The cases of mange reported here were diagnosed in 40 animals that were naturally infested by $C$. bovis. They were part of a herd of 112 Holstein cows housed in a free stall system on a farm located in a municipality $\left(28^{\circ} 51^{\prime} \mathrm{S} 51^{\circ} \mathrm{96} \mathrm{W}\right)$ in the northeastern mesoregion of the state of Rio Grande do Sul (RS), Brazil, during the months of June and July 2011. Epidemiological data and the clinical history of the disease were obtained and clinical examinations on the cows were carried out through visiting the farm. The mean number of lactations among the infested cows was $2.1( \pm 1.2)$ parturitions/cow, while the mean number of days of lactation was $207( \pm 142)$, and the mean milk production was $32.2( \pm 7.9) \mathrm{kg}$ of milk/day.

Deep skin scrapings from the base of the insertion of the tail and from the ischiorectal fossa were collected and placed in Petri dishes using a number 24 scalpel blade. These samples were identified with the number of each cow and were packed in an insulated box and transported to the Veterinary Parasitology Laboratory at the University of Passo Fundo (UPF). The scrapings were placed on slides, clarified with $10 \% \mathrm{KOH}$ and examined under an optical microscope (NEMATOLLAHI et al., 2007). A skin biopsy from one cow measuring approximately $1.5 \times 1.3$ $\times 0.7 \mathrm{~cm}$ was fixed in $10 \%$ buffered formalin and was sent for histopathological analysis at the Animal Pathology Laboratory of UPF. We measured the chest circumference of the $C$. bovis-positive animals to estimate their weight (HEINRICHS \& HARGROVE, 1987) in order to determine the treatment dosage. Subsequently,
$0.5 \%$ ivermectin in pour-on form was administered topically (Supramec Pour-On ${ }^{\circ}$, Intervet, Brazil) at a single dose of 0.5 $\mathrm{mg} / \mathrm{kg}$ of body weight on the dorsum of the animals, from the withers to the base of the tail. The animals were maintained under the same feeding and environmental conditions throughout the study period (28 days).

The cows were visually inspected every 7 days to monitor skin healing progress during the study period. The survival rates of the mites were also monitored at 7, 14, 21 and 28 days after treatment by performing deep skin scrapings as previously described. The animals were considered cured after total elimination of moving mites and mite eggs was observed. The infested cows were divided into two groups of 20 animals each based on their number of days of milk production: the early lactation group (101 \pm 59 days) and the late lactation group ( $314 \pm 119$ days). The cure rate following ivermectin pour-on treatment was evaluated in both groups. Statistical analysis was performed using MedCalc 12.6.1 (MEDCALC, 2011). The cure rate was compared between the groups based on calculation of survival curves generated according to the Kaplan-Meier method, and the statistical significance of the differences between the curves was determined via the log-rank procedure. $p$ values $<0.05$ were considered statistically significant (BEWICK et al., 2004).

\section{Results and Discussion}

Here, we have described a re-emerging C. bovis outbreak. The first description of this mite in cattle in RS was reported by Freire (1955). Since that time, this disease has not been reported. The re-emergence of $C$. bovis in RS can be attributed to epidemiological factors, such as climate change, management and indiscriminate and inappropriate use of antiparasitic drugs that may have selected resistant strains, as well as the absence of parasitological diagnosis. The high prevalence $(35.7 \%)$ of cows infested with $C$. bovis may be related to the husbandry practices applied to the herd. The outbreak occurred between the months of June and July, corresponding to the fall and winter seasons in southern Brazil. The animals were maintained in a free stall system characterized by overcrowding, lack of comfort and improper installations. The antiparasitic drugs used on the farm to control helminths were based on imidazole compounds that do not have acaricide action. However, use of formamidine-based products for tick control can lead to selection of resistant strains of $C$. bovis. Moreover, the presence of asymptomatic cows or latent mites may have facilitated the spread of the infestation in the herd (SMITH, 1967). Clinical cases of chorioptic mange are more frequent among housed animals, in densely populated environments, and during fall and winter (NEOG et al., 1992; YERUHAM et al., 1999). This type of disease is rare in the study region, but factors that increase predisposition towards the disease were present, thus indicating a reason for the re-emergence of this scabies outbreak.

Clinical examination revealed alopecia and crusted and thickened skin on the right or left side or on both sides of the base of the insertion of the tail, with spreading over the ischiorectal fossa (Figure 1). The parasitological diagnosis identified mites that were morphologically compatible with $C$. bovis (FACCINI \& MASSARD, 1976; ESSIG et al., 1999; ZAHLER et al., 2001). 

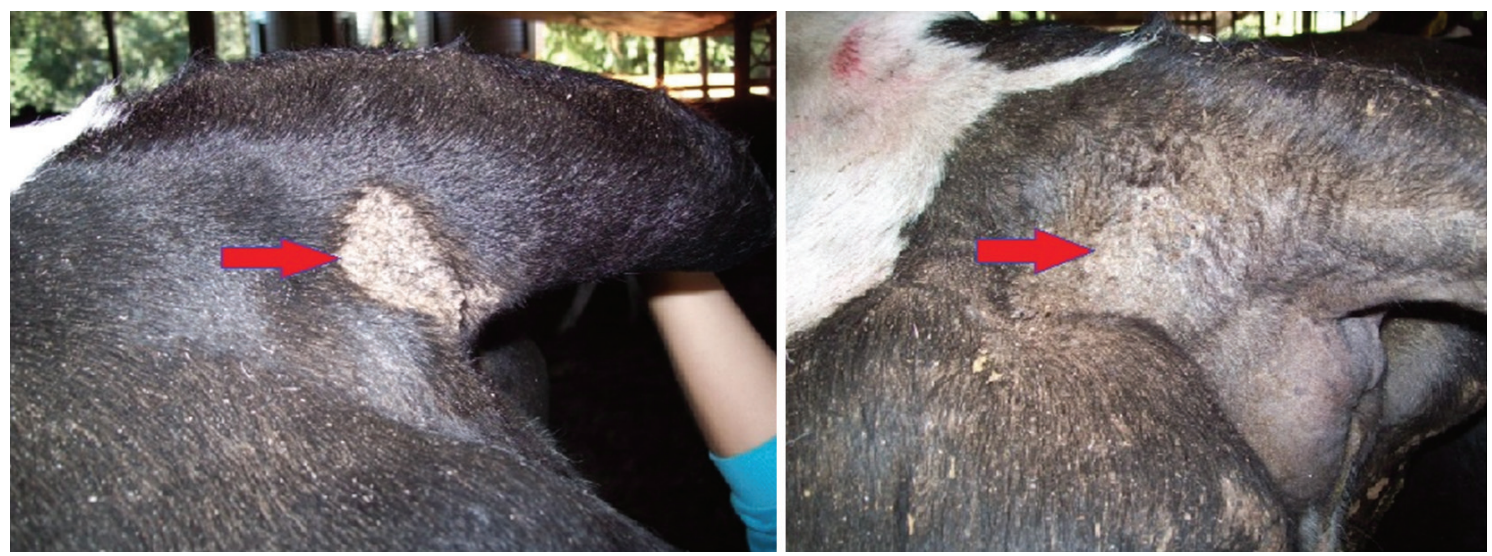

Figure 1. Clinical appearance of chorioptic mange in cattle (arrows) in the northeastern mesoregion of the state of Rio Grande do Sul, Brazil.

Macroscopic analysis on the skin fragment showed an irregular surface with crusts and with a grayish-brown to chestnut-brown color. At the time when the material for sections was collected, the skin fragment was grayish-white in color with a stiff consistency. Microscopic analysis revealed severe multifocal subacute eosinophilic lymphoplasmacytic perifolliculitis; moderate-tosevere multifocal subacute, sometimes suppurative, eosinophilic dermatitis; and mild multifocal suppurative folliculitis, with the presence of intraluminal mites in the follicles. Hyperkeratosis with crusting and microabscesses, bacterial colonies and some mites were also observed, along with hemorrhage, thus suggesting the presence of a chronic lesion. Histopathological analysis constitutes an important tool for diagnosing chorioptic mange, based on previous studies. The histopathological findings of this study were similar to those previously reported in case of Chorioptes infestations (HESTVIK et al., 2007). Consequently, since secondary bacterial infections were found in the integumentary system of cattle, in wounds induced by $C$. bovis, we concluded that this mite facilitated this type of secondary infection. Moreover, although the treatment of $C$. bovis was effective, lesions remained present. Thus, we also concluded that secondary infection contributes to the chronic nature of the injury.

The survival rate of the mite C. bovis assessed through the skin scrapings was showed be greater for cows in late lactation than for those in early lactation (Figure 2). The median time taken to achieve a cure was 14 days among the early-lactation cows and 21 days among the late-lactation cows. No significant involutions of the lesions or reinfection of the animals was observed after treatment. The cure rate with the treatment using $0.5 \%$ ivermectin in pour-on form was higher among the cows in early lactation than among those in late lactation $(p<0.0001)$. The different cure rates observed following the treatment applied to the early lactation cows $(100 \%)$, compared with the later-lactation cows (65\%), observed 28 days after the treatment, were probably due to herd management. At the beginning of the treatment, the cows in late lactation, which had been housed under the free stall system for a period of approximately 314 days, showed more widespread lesions, commonly associated with larger mite populations, compared with the cows in early lactation, which were introduced into the free stall system without visible lesions approximately 101 days before treatment.

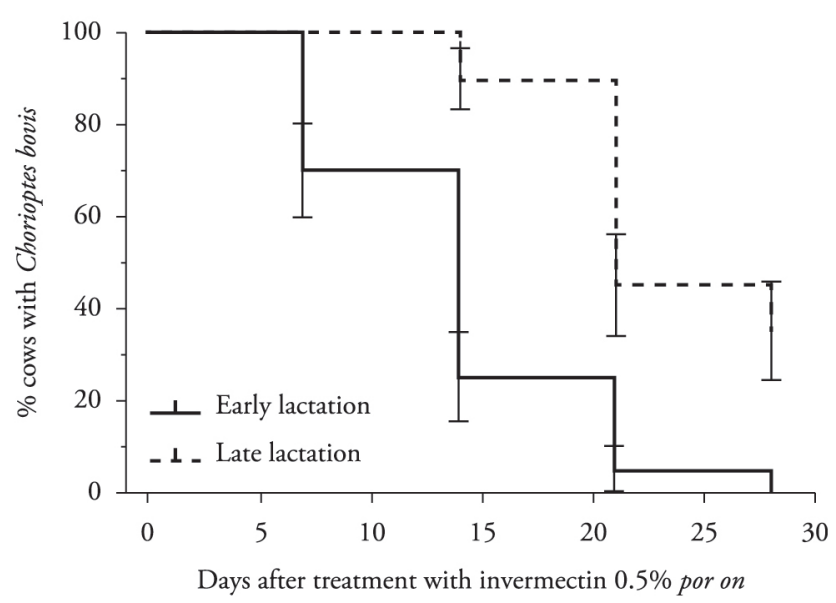

Figure 2. Kaplan-Meier survival curves corresponding to proportions of cows in early lactation (-) or in late lactation (--) infested with Chorioptes bovis following treatment with $0.5 \%$ ivermectin in pouron form.

Given the broad spectrum, ease of administration and low residual levels of pour-on ivermectin, topical application of this treatment has become a widely accepted practice (LAFFONT et al., 2003). We successfully obtained a reduction in C. bovis infestation in these cattle, thereby enabling continuation of milk production for human consumption. Villarroel \& Halliburton (2013) found that, in a herd of Holstein cows with chorioptic mange that were treated with $0.5 \%$ pour-on eprinomectin during dry-off, $32.1 \%$ of the animals had lesions after 12 months and required a second treatment. On the basis of these results, these authors concluded that eradication of chorioptic mange is difficult and that this difficulty is associated with persistence of the mites in the environment, thus requiring more than one treatment to control it.

\section{References}

Bewick V, Cheek L, Ball J. Statistics review 12: survival analysis. Crit Care 2004; 8(5): 389-394. http://dx.doi.org/10.1186/cc2955. PMid:15469602 
Essig A, Rinder H, Gothe R, Zahler M. Genetic differentiation of mites of the genus Chorioptes (Acari: Psoroptidae). Exp Appl Acarol 1999; 23(4): 309-318. http://dx.doi.org/10.1023/A:1006131402463. PMid:10399307

Faccini JL, Massard CL. [The genus Chorioptes gervais, 1895, parasite of ruminants in Brazil (Psoroptidae, Acarina)]. Rev Bras Biol 1976; 36(4): 871-872. PMid:1035808.

Faccini JLH, Leite AC. Combined chorioptic mange and dermatophilosis in a dairy cattle herd. Case report. Rev Bras Parasitol Vet 1996; 5(2): $127-128$

Fernandes BF, Basile JR, Baroni JM, Busetti ET. Sarna corióptica em bovino do Paraná. Arq Biol Tecnol 1972; 15: 70-72.

Freire JJ. Sarna corióptica no Rio Grande do Sul. Bol Dir Prod Ani 1955; 12(23): 15-23.

Heinrichs AJ, Hargrove GL. Standards of weight and height for Holstein heifers. J Dairy Sci 1987; 70(3): 653-660. http://dx.doi.org/10.3168/ jds.S0022-0302(87)80055-3. PMid:3584605

Hestvik G, Zahler-Rinder M, Gavier-Widén D, Lindberg R, Mattsson R, Morrison D, et al. A previously unidentified Chorioptes species infesting outer ear canals of moose (Alces alces): characterization of the mite and the pathology of infestation. Acta Vet Scand 2007; 49(1): 21. http://dx.doi. org/10.1186/1751-0147-49-21. PMid:17825115

Jones J, Jenkins T, Webb L, Davies A, Bates P. Psoroptic mange in cattle in south Wales. Vet Rec 2008; 162(14): 460. http://dx.doi.org/10.1136/ vr.162.14.460-b. PMid:18390862

Laffont CM, Bousquet-Mélou A, Bralet D, Alvinerie M, Fink-Gremmels J, Toutain PL. A pharmacokinetic model to document the actual disposition of topical ivermectin in cattle. Vet Res 2003; 34(4): 445-460. http://dx.doi.org/10.1051/vetres:2003014. PMid:12911861
MedCalc. Manual MedCalc Statistical Software. Mariakerke: Broekstraat $52 ; 2011$

Nematollahi A, Moghaddam GA, Golezardy H. An outbreak of Chorioptes bovis mange on a dairy farm in Tabriz, Iran. Iran J Vet Res 2007; 8(4): 351-354

Neog R, Borkakoty MR, Lahkar BC. Mange mite infestation in goats in Assam. Indian Vet J 1992; 69(10): 891-893.

Oba MS, Ogassawara S, Costa AJ. [The occurrence of Chorioptes bovis in bovines in the region of São Carlos, State of São Paulo (author's transl)]. Arq Inst Biol (Sao Paulo) 1977; 44(1-2): 95-97. PMid:607916.

Rehbein S, Winter R, Visser M, Maciel AE, Marley SE. Chorioptic mange in dairy cattle: treatment with eprinomectin pour-on. Parasitol Res 2005; 98(1): 21-25. http://dx.doi.org/10.1007/s00436-005-0005-y. PMid:16240128

Smith HJ. A preliminary trial on the efficacy of ciodrin against Chorioptes bovis in cattle. Can Vet J 1967; 8(4): 88-90. PMid:6069018.

Villarroel A, Halliburton MK. Control of extensive chorioptic mange natural infection in lactating dairy cattle without milk withdrawal. Vet J2013; 197(2): 233-237. http://dx.doi.org/10.1016/j.tvjl.2013.01.003. PMid:23402707

Yeruham I, Rosen S, Hadani A. Chorioptic mange (Acarina: Psoroptidae) in domestic and wild ruminants in Israel. Exp Appl Acarol 1999; 23(11): 861-869. http://dx.doi.org/10.1023/A:1006217016688. PMid:10668861

Zahler M, Hendrikx WML, Essig A, Rinder H, Gothe R. Taxonomic reconsideration of the genus Chorioptes Gervais and van Beneden, 1859 (Acari: Psoroptidae). Exp Appl Acarol 2001; 25(6): 517-523. http:// dx.doi.org/10.1023/A:1011857802317. PMid:11697788 